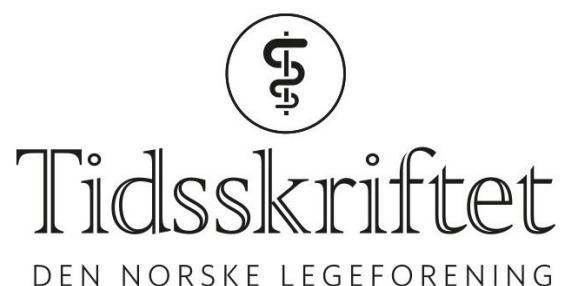

DEN NORSKE LEGEFORENING

\title{
Humanisme på speed
}

KOMMENTAR

\section{EIVIND MELAND}

E-post: eivind.meland@uib.no

Eivind Meland er fastlege og professor.

Ingen oppgitte interessekonflikter.

Det er fortjenestefullt at to unge kolleger løfter fram grunnleggende problemstillinger om medisinens mål og mening (1). Det er tydelig at deres perspektiv ikke ble politisk belyst i en valgkamp der alle synes å mene at medisinens moralske etos er underforstått og selvfølgelig. Det er også våkent å knytte denne kollektive blindheten til førkrigstiden og fascismens fremmarsj. Det dreier seg om et allment problem knyttet til «humanisme på speed» eller menneskelig overmot og overtro på vitenskapens muligheter og grenseløse rett til å kontrollere og styre våre livsbetingelser.

De har også rett i at sykeligheten knyttet til den «tredje sykdomsbølgen» med subjektive helseplager og funksjonssvikt ikke kan møtes med en tradisjonell «maskin- og algoritmefeil»-modell. Tvert om synes det som om medisinen og vitenskapen med sitt ytre diagnostiserende objektsyn er en del av problemet heller enn en del av løsningen. Det jeg savner fra Vogt og Pale er at de erkjenner at det finnes alternative etiske horisonter i vår samtid som vi kan støtte og stimulere: Ett slikt perspektiv finner vi innen psykoterapien i den såkalte aksepterings- og forpliktelsesterapien. Det er et perspektiv som introduserer forsoning, selvforsoning og vennlighet som alternativ til krampaktig og hensiktsløs (selv)kontroll. Det løfter også frem at vi som mennesker er moralske og meningss $\varnothing$ kende aktører i våre liv. En medisin som i stedet for å forføre folk inn i forestillingen om at livet skal bli sykdoms- og symptomfritt, kan vi få en medisin som hjelper folk med å leve moralsk oppreist med forankring i de verdiene som hver av oss opplever som våre egne. Det vil bety en forskjell!

\section{LITTERATUR:}

1. Vogt H, Pahle A. Evig liv som medisinsk mål. Tidsskr Nor Legeforen 2017; 137: 1158 - 9.

[PubMed][CrossRef]

Publisert:30. oktober 2017. Tidsskr Nor Legeforen. DOI:10.4045/tidsskr.17.0823

(C) Tidsskrift for Den norske legeforening 2020. Lastet ned fra tidsskriftet.no 